\title{
THE USE OF FUZZY LOGIC IN CORPORATE INNOVATIVE POTENTIAL ASSESSMENT
}

\section{Tomasz L. Nawrocki}

Silesian University of Technology, Zabrze, Poland

e-mail: tomasz.nawrocki@polsl.pl

ORCID: 0000-0002-2120-3494

(C) 2019 Tomasz L. Nawrocki

This is an open access article distributed under the Creative Commons Attribution-NonCommercial-NoDerivs license (http://creativecommons.org/licenses/by-nc-nd/3.0/)

DOI: 10.15611/eada.2019.1.03

JEL Classification: C69, M10, O32, Q55

\begin{abstract}
The paper aims to present an empirical application of an originally developed model for corporate potential innovativeness assessment and comparison. The proposed model provides a framework for combined static and dynamic potential innovativeness assessment with the use of fuzzy logic. Fuzzy logic is used to assess corporate potential innovativeness from two perspectives: resources conditioning innovation activities in an enterprise, and the engagement of an enterprise in their continuous development. In this context, selected companies from the information technology sector listed on the Warsaw Stock Exchange were examined. The need for corporate innovativeness measurement and evaluation for management purposes arises from its growing importance in building enterprise value and achieving long-term competitive advantage. The proposed model enables the fairly current and good orientation in both general and a more in-depth innovativeness potential level of the assessed enterprises. This can be the basis for various comparison analysis and managerial decisions regarding e.g. innovation management as well as managing corporate image and reputation.
\end{abstract}

Keywords: corporate innovative potential, innovativeness assessment, fuzzy logic, Mamdani fuzzy model.

\section{Introduction}

In the literature, innovation and innovativeness have been for many years seen as the driving forces of economic development, which was first pointed out by Joseph A. Schumpeter in his vision of creative destruction referring to the mechanism of changes in a capitalist economy [Schumpeter 1960]. Although the theory of innovation proposed by Schumpeter refers to the economy in the first half of the 20th century, the importance of this phenomenon has not devalued over time, but on the contrary, it has become one of the main determinants of competitiveness [Prahalad, Hamel 1990; Drucker 1992; Porter 1998], revenue growth [Patterson 1998] and organizational survival [Hurley, Hult 1998]. 
At the same time, despite the great interest of the scientific community in innovation and the innovativeness phenomenon over the years, it is hard to talk about some generally accepted definitions. Understanding innovativeness, as well as innovation itself, has been considered by particular researchers in many different contexts. The term innovation is on the one hand related only to significantly changed or new solutions [OECD and Eurostat 2005], and on the other, identified with all changes recognized by people as a novelty in relation to the previous state [Kotler 1994]. Innovations are also considered in terms of the subject - as a result (here there is an additional distinction between product, process, marketing and organizational innovations), or in functional terms - as a process [Goldsmith, Foxall 2003]. A similar diversification of perception concerns the issue of innovativeness. Most often it is emphasized that innovativeness is a specific ability or skill of an enterprise to search for, implement and disseminate innovations continuously [Pomykalski 2001]. Consequently, possessing it allows the enterprise to implement new products, processes, or ideas [Hult et al. 2004]. More extended definitions depict innovativeness as an organization's inclination to seek, create, and implement new products, technologies, services, markets, and management methods; to undertake actions in uncertain situations; to monitor the market and competition, forecast market situations and react quickly to changes by breaking routines, changing ways of communicating, and developing new ways of organizing [Francik 2003]. It should also be noted that many definitions of innovativeness go beyond merely exposing the same abilities or skills, emphasizing the results of its possession and use. In this way, innovativeness is the ability of an organization to control and maintain high dynamics of value creation, which manifests itself in using the occasion to generate change and to process, as well as implement, new ideas in practice [Jin, Hewitt-Dundas, Thompson 2004] earlier than other enterprises [Rogers 1995]. Innovativeness as an ability should also enable the effective allocation of resources, aiming at creating the optimal configuration of competitive advantage [Morgan, Berthon 2008].

Therefore, innovativeness can be seen in the context of the widely understood potential for creating innovation and continuous engagement in its development, the so-called potential innovativeness or innovative potential as well as innovation capabilities, and in the context of specific effects of undertaken innovative activities as well as their impact on the enterprise's financial results - the so-called resultant innovativeness [Nawrocki 2012; Yeung, Lai, Yee 2007]. Differentiation between these two types of organizational innovativeness is very important, as high innovative potential does not necessarily translate into good results of innovative activity [Simpson, Siguaw, Enz 2006] which, among others, refers to the issue of innovation management.

The pressure on innovation and innovativeness in recent years is particularly strong and visible in a variety of contexts. It can be said that everyone wants to be 
perceived as 'innovative'. The images of innovative countries, innovative regions, innovative cities or innovative companies are created. In capital markets separate segments were created, dedicated mostly to innovative companies in particular (e.g. the NASDAQ in the United States and the New Connect segment in Poland, as well as the earlier TECHWIG index). Unfortunately, due to the width and complexity, and therefore ambiguity, of the innovation and innovativeness concept, in recent years it can be seen that different entities, especially companies, very easily identify themselves as innovative. What is worse, this phenomenon is becoming more intensive over time. The reasons for such actions arise from the fact that innovativeness, regardless of the documented positive impact on the development of economies or corporate results, is associated with a certain prestige and inspires respect, which even with very limited, or even pretended, innovative activities can easily be used in marketing operations and thereby translate into market success. Therefore, particular importance is given to the possibility of the quick and possible objective assessment of companies' innovativeness, which should allow for their reliable differentiation. Such an assessment could also be useful in the inter-company innovation management process, as well as its image and reputation management.

In the literature we find various approaches to the corporate or organizational innovativeness measurement/assessment, which can be gathered in several groups. The first one consists of methods used by different international and national institutions (e.g. Eurostat, Central Statistical Office of Poland) to investigate periodic innovative phenomena: the Frascati Manual - recommendations regarding the evaluation of companies' engagement in research and development [OECD 2015], and also the Oslo Manual - recommendations regarding collecting and analysing data in reference to widely understood innovative activity [OECD and Eurostat 2005]. The second group involves methods based on the resource approach, which includes the concept of strategic management with the focus on investigating an organisation's resources and skills [e.g. Pawłowski 2005]. The third group consists of methods focusing on the time factor, specifically emphasizing the moment of implementing an innovation in relation to the competition - historical, cross-sectional and complex methods [e.g. Rogers 1995]. Clearly, apart from the abovementioned methods, there are many others that can be traced in the literature, but they are merely some modifications or compilations of them.

However, at the same time, it is quite often stated that most of the innovation/ innovativeness studies are generally quite radically affected by various kinds of drawbacks such as: very narrow perception of innovativeness, problematic data updating, lack of synthetic innovativeness measure/assessment or generalization of final results [e.g. Lev 2001; Mazzucato 2006]. Therefore, to fill the gap in this area, the author conducts research on developing a corporate innovativeness assessment model based on the use of fuzzy logic and publicly available sources of innovation. The aim of this paper is to present a practical application of the designed so far 
versions of the model focused on corporate innovative potential (innovation capabilities) based on the example of selected IT companies - software developers - listed on the Warsaw Stock Exchange (WSE).

\section{Basic assumptions and methodology}

The version proposed in this paper of the corporate potential innovativeness assessment model is the next stage of its development and is slightly modified in relation to the concept published in the ICoM 2017 Conference Proceedings [Nawrocki 2017]. In contrast to the statistical and econometric methods used for example in evaluating an enterprise's financial situation, the assessment criteria selection in the proposed original solution were carried out arbitrarily taking into account the resource based view of strategic management, informational value of periodical reports published by companies, and the author's experience in the field of corporate innovativeness research and analysis.

The suggested methodology of corporate innovative potential assessment is supposed to be of a universal character (no sectoral restrictions) and dedicated especially for enterprises which publish annual reports, a periodical actualization of input data and thus the generation of new results. This involves two aspects: (i) the widely understood resources determining innovative activity and (ii) engagement in its continuous development.

Within the resources determining innovative activity (i) there were three generic areas distinguished: intellectual resources, material resources, and financial resources. In the case of the first generic area the partial assessment criteria include: assessment of human capital resulting from work efficiency as well as the quality/ competences of employees, and assessment of knowledge in the form of intangible assets excluding goodwill based on workforce equipment in intangibles and their depreciation and amortization ratio. In the case of the material resources area, the partial assessment criteria involve: workforce equipment in machinery and its depreciation and amortization ratio. Furthermore, considering financial resources area, the partial assessment criteria include cash financing possibilities regarding intangibles and machinery as well as credit rating, which show the possibilities of obtaining debt capital and consists of financial liquidity assessment as well as debt level and ability to its service assessments.

In the assessment of an enterprise's engagement in development of resources determining innovative activity (ii), there are also three clear generic areas: engagement in intellectual, material and financial resources development. For the first of them the partial assessment criteria include: assessment of human capital development, resulting from percentage employment, as well as salaries and benefits per employee year to year growth rate, and assessment of knowledge in the form of intangible assets development, based on their year to year growth in relation to total assets from previous year and intensity ratio of investment in intangibles. In the case 
of the second area, the partial assessment criteria include: machinery year to year growth in relation to total assets from the previous year as well as the intensity ratio of investment in machinery. Furthermore, considering engagement in financial resources development, the partial assessment criteria include: cash creation results resulting from financial surplus to general expenses ratio as well as cash year to year growth in relation to total assets from the previous year, and year to year growth of net working capital in relation to total assets from the previous year.

As for modifications to the concept proposed on ICoM2017 [Nawrocki 2017], which appeared in the course of further empirical applications of the model, they refer to:

- detailing property, plant and equipment assets to machinery (property, plant and equipment assets consist usually in property, machinery, means of transport, fixed assets under construction and others, of which mainly machinery has a real impact on the innovation capabilities of company; taking into account the whole value of mentioned assets could be too much of a generalization);

- replacement of intangibles as well as property, plant and equipment productivity ratios by workforce equipment in intangibles and machinery ratios (productivity ratios, especially in regard to intangibles, often gave confusing results when a company had small assets);

- replacement of "covering investment expenses in cash" by "cash financing possibilities regarding intangibles and machinery" (the new form of ratio gives a better picture of financing possibilities in the area of intangibles and machinery; it concentrates on a company's real state of possession and not only the percentage growth rate);

- relativization of intangibles and machinery year to year growth through dividing by value of total assets from the previous year (such an approach to the change of the aforementioned categories has a more complete character then a simple percentage year to year change, because it also reveals its scale in a valuable aspect);

- replacement of "financial surplus to investment and financial expenses ratio" by "financial surplus to general expenses ratio", which also includes expenses on net working capital (including in this ratio expenses on net working capital is important as sometimes they are as significant, or even higher, as investment and financial expenses).

The structure of the proposed corporate potential innovativeness assessment model, along with the most detailed assessment criteria within the particular modules, is presented in Figure 1. In the proposed model firstly it is supposed to obtain partial assessments within the distinguished basic assessment criteria, which result from ratios calculated on the basis of data from annual reports. Next, aggregated assessments' results may be obtained in the areas of intellectual, material and financial resources, as well as engagement in the development of each of these three types of resources. Furthermore, these results constitute the foundations for calculating general assessments in the areas of resources' innovative potential and 


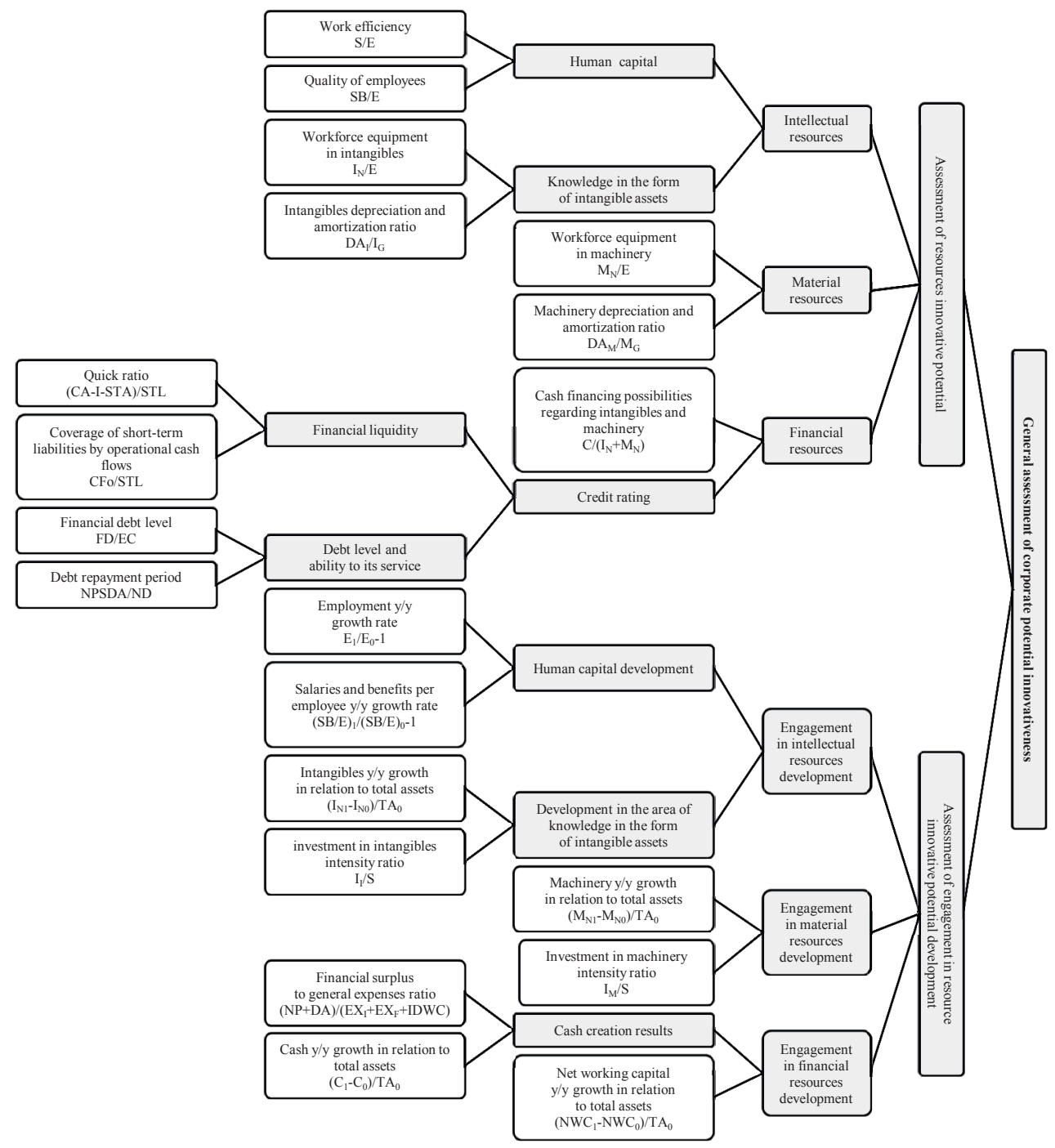

$\mathrm{S}$ - Sales Revenues, E - Employees, SB - Salaries and Benefits, $\mathrm{I}_{\mathrm{N}}-$ Net Value of Intangibles (without Goodwill), DA - Depreciation and Amortization of Intangibles (without Goodwill), $\mathrm{I}_{\mathrm{G}}$ - Gross Value of Intangibles (without Goodwill), $\mathrm{M}_{\mathrm{N}}$ - Net Value of Machinery, $\mathrm{DA}_{\mathrm{M}}-$ Depreciation and Amortization of Machinery, $\mathrm{M}_{\mathrm{G}}-$ Gross Value of Machinery, $\mathrm{C}-\mathrm{Cash}, \mathrm{QR}-$ Quick Ratio (Current Assets less Inventories and Short-term Accruals to Short-term Liabilities), CFo - Cash Flows from Operational Activity, STL - Short-term Liabilities, FD - Financial Debt, EC - Equity Capital, NPSDA - Net Profit from Sales + Depreciation and Amortization, ND - Net Debt (FD - C), $\mathrm{I}_{\mathrm{I}}$ - Expenses on Intangibles, $\mathrm{I}_{\mathrm{M}}-$ Expenses on Machinery, NP - Net Profit, DA - Depreciation and Amortization, $\mathrm{EX}_{\mathrm{F}}-$ Financial Expenses, IDWC - Increase of Demand for Working Capital, TA - Total Assets, NWC - Net Working Capital, $\mathrm{y} / \mathrm{y}-$ year to year.

Fig. 1. General structure of corporate potential innovativeness assessment model

Source: own work based on [Nawrocki 2017]. 
engagement in its development, so that in the final stage, on their basis, it is possible to achieve a general corporate potential innovativeness assessment.

It must be noted that the proposed solution differs from the views on the innovative capabilities of an organization often presented in recent literature, which are mainly focused on an environment conductive to entrepreneur behaviour considered by the prism of such determinants as: top management support, work discretion/autonomy, rewards/reinforcement, time availability and organizational boundaries [e.g. Kuratko, Hornsby, Covin 2014]. On the one hand it is hard to argue with the significance of such an approach but on the other it should be noted that, firstly, it concentrates only on one form of organizational resources (intellectual), omitting material and financial resources, which are obviously less but nevertheless also important in an innovation activity, and, secondly, such categories as mentioned above are of a soft nature and difficult to measure in any other way then by a survey with all the disadvantages of this method. Therefore the proposed method, although not allowing, due to the information value of the enterprises' periodic reports, to fully take into account the entrepreneurial environment assessment, has other advantages that significantly support its usefulness.

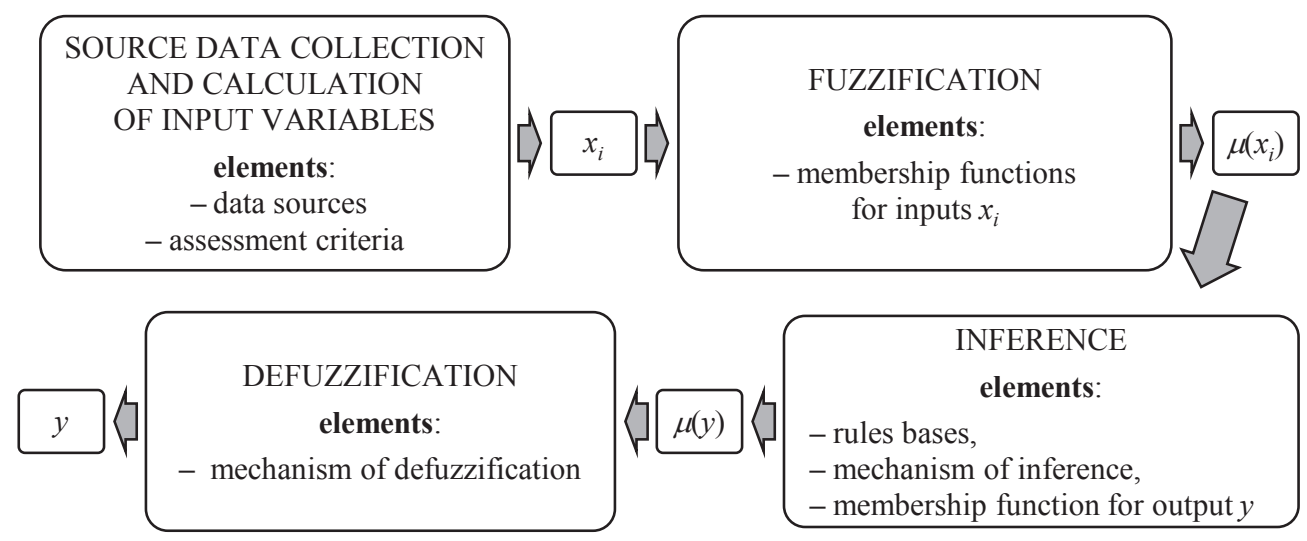

Fig. 2. Construction process scheme of corporate potential innovativeness assessment of a fuzzy model Source: own work based on [Piegat 2003].

The calculation apparatus in the suggested solution is based on the fuzzy set theory [Zadeh 1965; Piegat 2003], which is one of the approximate reasoning methods. Thus, based on the general model structure (Figure 1), the fuzzy model had to be developed. In relation to its construction process (Figure 2) the Mamdani approach was used [Mamdani, Assilian 1975].

There were also some assumptions made regarding individual stages of the fuzzy model construction process:

- for all input variables of the model, the same dictionary of linguistic values was used, and their value space was divided into three fuzzy sets called \{low, medium, high $\}$; 
- for output variables of the model, in order to obtain more accurate intermediate assessments, the space of linguistic values was divided into five fuzzy sets called \{low, mid-low, medium, mid-high, high\};

- in the case of all membership functions to the particular fuzzy sets, a triangular shape was decided for them (Figures 3 and 4);

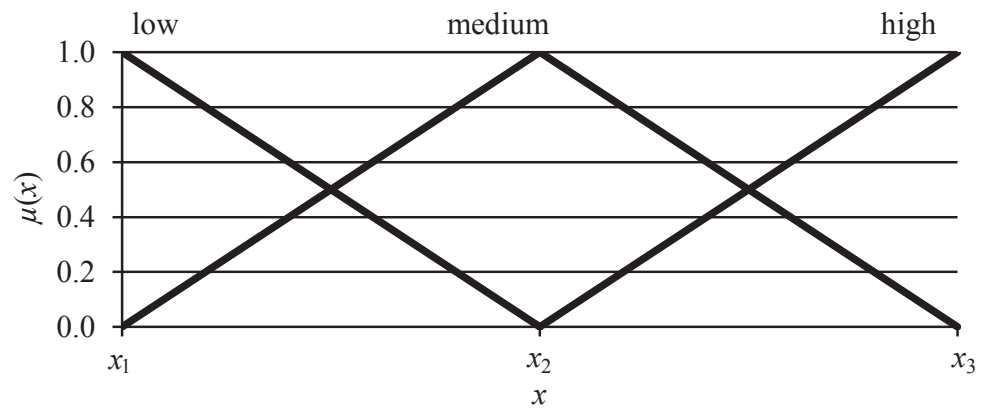

Fig. 3. The input variables membership function to distinguished fuzzy sets

Source: own work.

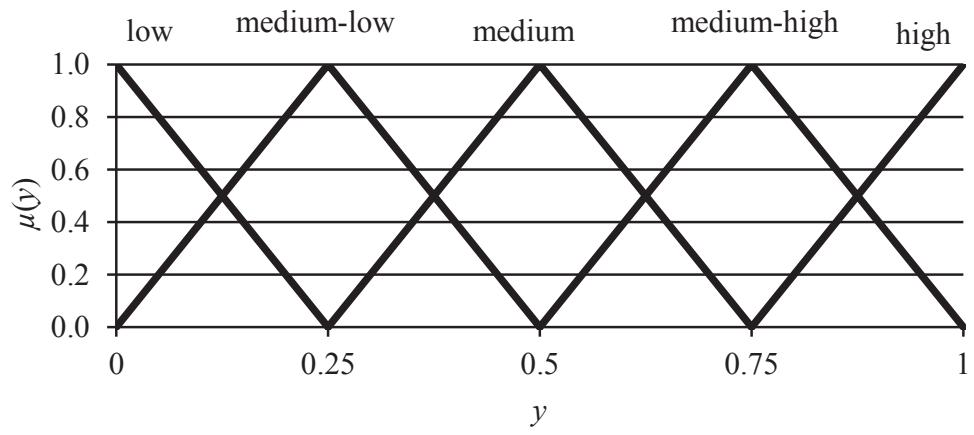

Fig. 4. The output variables membership function to distinguished fuzzy sets

Source: own work.

- the values of the fuzzy sets' characteristic points $\left(x_{1}, x_{2}, x_{3}\right)$ for the particular input variables of the model were determined partly based on the literature on the enterprises' financial analysis and partly arbitrarily, based on the distribution of the analysed variables values and on the author's experience in the considered field (Table 1);

- fuzzification of input variables was carried out with the use of a simple linear interpolation method;

- fuzzy reasoning in the particular knowledge bases of the model was conducted using PROD operator (fuzzy implication) and SUM operator; 
- for defuzzification of fuzzy reasoning results within the particular rule bases a simplified Canter of Sums method was used.

Next, taking into consideration the general structure of the corporate potential innovativeness assessment model presented in Figure 1 and the author's experience in the area of the analysed issue, we created 17 rules bases in the form of "IF - THEN" sentences ( 15 bases with 9 rules and 2 bases with 27 rules), achieving in this way a 'ready to use' form of fuzzy model. Due to the large volume of all the rules bases included in the proposed model, below are presented only the last three of them.

Table 1. The values of fuzzy sets' characteristic points for particular input variables of the corporate potential innovativeness assessment fuzzy model

\begin{tabular}{|c|c|c|c|}
\hline Name of input variable & $\begin{array}{c}x_{1} \\
\mu(x)=1 / \text { low }\end{array}$ & $\begin{array}{c}x_{2} \\
\mu(x)=1 / \text { medium }\end{array}$ & $\begin{array}{c}x_{3} \\
\mu(x)=1 / \text { high }\end{array}$ \\
\hline Work efficiency [thousands of PLN per employee] & 0 & 175 & 350 \\
\hline Quality of employees [thousands of PLN per employee] & 0 & 75 & 150 \\
\hline $\begin{array}{l}\text { Workforce equipment in intangibles [thousands of PLN } \\
\text { per employee] }\end{array}$ & 0 & 25 & 50 \\
\hline Intangibles depreciation and amortization ratio & 0.1 & 0.5 & 0.9 \\
\hline $\begin{array}{l}\text { Workforce equipment in machinery [thousands of PLN } \\
\text { per employee] }\end{array}$ & 0 & 12.5 & 25 \\
\hline Machinery depreciation and amortization ratio & 0.1 & 0.5 & 0.9 \\
\hline Quick ratio & 0 & 0.75 & 1.5 \\
\hline $\begin{array}{l}\text { Coverage of short-term liabilities by operational cash } \\
\text { flows }\end{array}$ & 0 & 0.75 & 1.5 \\
\hline Financial debt level & 0 & 1 & 2 \\
\hline Debt repayment period [years] & 0 & 3 & 6 \\
\hline $\begin{array}{l}\text { Cash financing possibilities regarding intangibles and } \\
\text { machinery }\end{array}$ & 0 & 0.5 & 1 \\
\hline Employment year to year growth rate & -0.05 & 0.025 & 0.1 \\
\hline $\begin{array}{l}\text { Salaries and benefits per employee year to year growth } \\
\text { rate }\end{array}$ & -0.1 & 0.025 & 0.15 \\
\hline Intangibles year to year growth in relation to total assets & -0.04 & 0.01 & 0.06 \\
\hline Intensity ratio of investment in intangibles & 0 & 0.1 & 0.2 \\
\hline Machinery year to year growth in relation to total assets & -0.02 & 0.005 & 0.03 \\
\hline Intensity ratio of investment in machinery & 0 & 0.05 & 0.1 \\
\hline Financial surplus to general expenses ratio & -1 & 0.25 & 1.5 \\
\hline Cash year to year growth in relation to total assets & -0.05 & 0.025 & 0.1 \\
\hline $\begin{array}{l}\text { Net working capital year to year growth in relation to } \\
\text { total assets }\end{array}$ & -0.05 & 0.025 & 0.1 \\
\hline
\end{tabular}

Source: own work.

Rules base for assessment of resources innovative potential - RIP (IR intellectual resources, $M R$ - material resources, $F R$ - financial resources) and engagement in resource innovative potential development - ERIPD (EIRD, EMRD, 
$E F R D$ - engagement in respectively - intellectual, material and financial - resources development). In both cases, due to the similar perception of individual resources, it was decided to use the same rules base:

R1: IF IR/ERID is low AND MR/ERMD is low AND FR/EFRD is low THEN RIP/ERIPD is low R2: IF IR/ERID is low AND MR/ERMD is low AND FR/EFRD is medium THEN RIP/ERIPD is low R3: IF $I R / E R I D$ is low AND MR/ERMD is medium AND FR/EFRD is low THEN RIP/ERIPD is low R4: IF IR/ERID is low AND MR/ERMD is medium AND FR/EFRD is medium THEN RIP/ERIPD is low-mid

R5: IF IR/ERID is medium AND MR/ERMD is low AND FR/EFRD is low THEN RIP/ERIPD is low-mid R6: IF IR/ERID is medium AND MR/ERMD is medium AND FR/EFRD is low THEN RIP/ERIPD is low-mid

R7: IF IR/ERID is low AND MR/ERMD is low AND FR/EFRD is high THEN RIP/ERIPD is low-mid R8: IF IR/ERID is low AND MR/ERMD is high AND FR/EFRD is low THEN RIP/ERIPD is low-mid R9: IF IR/ERID is low AND MR/ERMD is high AND FR/EFRD is medium THEN RIP/ERIPD is lowmid

R10: IF IR/ERID is medium AND MR/ERMD is low AND FR/EFRD is medium THEN RIP/ERIPD is medium

R11: IF IR/ERID is medium AND MR/ERMD is medium AND FR/EFRD is medium THEN RIP/ ERIPD is medium

R12: IF IR/ERID is low AND MR/ERMD is high AND FR/EFRD is high THEN RIP/ERIPD is medium R13: IF IR/ERID is high AND MR/ERMD is low AND FR/EFRD is low THEN RIP/ERIPD is medium R14: IF IR/ERID is medium AND MR/ERMD is medium AND FR/EFRD is high THEN RIP/ERIPD is medium

R15: IF IR/ERID is medium AND MR/ERMD is high AND FR/EFRD is medium THEN RIP/ERIPD is medium

R16: IF IR/ERID is low AND MR/ERMD is medium AND FR/EFRD is high THEN RIP/ERIPD is medium

R17: IF IR/ERID is medium AND MR/ERMD is low AND FR/EFRD is high THEN RIP/ERIPD is medium

R18: IF IR/ERID is medium AND MR/ERMD is high AND FR/EFRD is low THEN RIP/ERIPD is medium

R19: IF IR/ERID is high AND MR/ERMD is medium AND FR/EFRD is low THEN RIP/ERIPD is medium

R20: IF IR/ERID is high AND MR/ERMD is low AND FR/EFRD is medium THEN RIP/ERIPD is medium

R21: IF IR/ERID is high AND MR/ERMD is high AND FR/EFRD is low THEN RIP/ERIPD is midhigh

R22: IF IR/ERID is high AND MR/ERMD is low AND FR/EFRD is high THEN RIP/ERIPD is midhigh

R23: IF IR/ERID is medium AND MR/ERMD is high AND FR/EFRD is high THEN RIP/ERIPD is mid-high

R24: IF IR/ERID is high AND MR/ERMD is medium AND FR/EFRD is medium THEN RIP/ERIPD is mid-high

R25: IF IR/ERID is high AND MR/ERMD is high AND FR/EFRD is medium THEN RIP/ERIPD is high

R26: IF IR/ERID is high AND MR/ERMD is medium AND FR/EFRD is high THEN RIP/ERIPD is high

R27: IF IR/ERID is high AND MR/ERMD is high AND FR/EFRD is high THEN RIP/ERIPD is high 
Rules base for general assessment of corporate potential innovativeness - CPI (RIP, ERIPD):

R1: IF RIP is low AND ERIPD is low THEN CPI is low

R2: IF RIP is low AND ERIPD is medium THEN CPI is low-mid

R3: IF RIP is low AND ERIPD is high THEN CPI is low-mid

R4: IF RIP is medium AND ERIPD is low THEN CPI is low-mid

R5: IF RIP is medium AND ERIPD is medium THEN CPI is medium

R6: IF RIP is medium AND ERIPD is high THEN CPI is mid-high

R7: IF RIP is high AND ERIPD is low THEN CPI is mid-high

R8: IF RIP is high AND ERIPD is medium THEN $C P I$ is high

R9: IF RIP is high AND ERIPD is high THEN CPI is high

It is also worth noting that the intermediate and final assessments generated by the model take values in the range between 0 and 1 , where from the viewpoint of the analysed issue, values closer to 1 mean a very favourable result (higher innovativeness), while values closer to 0 indicate less favourable results (lower innovativeness).

All the calculations related to the presented fuzzy model were based on the selfdeveloped structure of formulas in MS Excel.

\section{Results and discussion}

A sample practical application of the proposed model to corporate potential innovativeness assessment was performed for eight software developers (creating mainly ERP software for SMEs), whose shares are listed on the Warsaw Stock Exchange: Asseco Business Solutions (Asseco BS), Asseco Poland, Asseco SouthEastern Europe (Asseco SEE), Comarch, LSI Software, Simple, Sygnity and Quantum Software.

According to the adopted methodology, the basis for the potential innovativeness assessment of the abovementioned companies were input variables calculated with the use of data acquired from their annual reports for 2017 (Table 2).

The results obtained for the studied companies during the research within individual modules of the considered fuzzy model are presented in Figure 5 (final assessments) and Table 3 (intermediate assessments).

Taking into account the obtained results, it can be concluded that in terms of potential innovativeness there is no clear leader among the studied entities. The toprated companies - Asseco Poland and Asseco SEE - obtained final assessments at the level slightly above average, 0.58 and 0.57 respectively. Both companies had very similar assessments in the area of resources innovative potential $(0.65 / 0.64)$ and engagement in resource innovative potential development $(0.41 / 0.40)$. However, looking into intermediate assessments (Table 3), it must be noted that the final result of Asseco SEE is mostly affected by the material resources area related to a large extent to the specificity of this company's business (one of the main segments is creating an infrastructure - POS terminals and ATMs - that is then leased to clients 
Table 2. The non-fuzzy values of investigated companies' assessment criteria (input variables)

\begin{tabular}{|c|c|c|c|c|c|c|c|c|}
\hline Name of input variable & 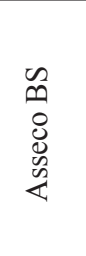 & 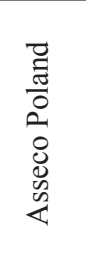 & 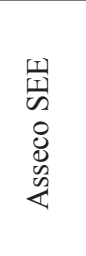 & 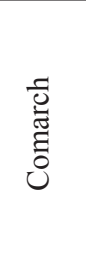 & 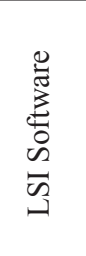 & $\begin{array}{l}\frac{\vec{a}}{\vec{\Xi}} \\
\text { ज्ञ }\end{array}$ & 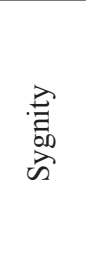 & 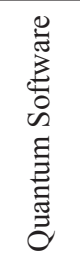 \\
\hline Work efficiency & 271 & 337 & 378 & 200 & 243 & 203 & 301 & 185 \\
\hline Quality of employees & 122 & 167 & 120 & 117 & 71 & 75 & 123 & 79 \\
\hline $\begin{array}{l}\text { Workforce equipment } \\
\text { in intangibles }\end{array}$ & 27.24 & 69.60 & 15.94 & 11.32 & 52.27 & 45.40 & 27.11 & 1.69 \\
\hline $\begin{array}{l}\text { Intangibles depreciation } \\
\text { and amortization ratio }\end{array}$ & 0.59 & 0.39 & 0.72 & 0.75 & 0.62 & 0.57 & 0.83 & 0.92 \\
\hline $\begin{array}{l}\text { Workforce equipment } \\
\text { in machinery }\end{array}$ & 7.18 & 9.92 & 64.65 & 9.50 & 1.05 & 1.07 & 3.21 & 3.01 \\
\hline $\begin{array}{l}\text { Machinery depreciation } \\
\text { and amortization ratio }\end{array}$ & 0.67 & 0.73 & 0.48 & 0.73 & 0.88 & 0.88 & 0.90 & 0.71 \\
\hline Quick ratio & 0.85 & 0.91 & 1.49 & 1.69 & 1.20 & 0.91 & 0.60 & 3.74 \\
\hline $\begin{array}{l}\text { Coverage of st. liabilities } \\
\text { by operational cf }\end{array}$ & 1.02 & 0.15 & 0.56 & 0.16 & 0.46 & 0.27 & -0.07 & 0.92 \\
\hline Financial debt level & 0.12 & 0.18 & 0.07 & 0.27 & 0.09 & 0.42 & 2.00 & 0.02 \\
\hline Debt repayment period & 0.32 & 0.38 & 0.00 & 0.25 & 0.03 & 0.46 & 10.00 & 0.00 \\
\hline $\begin{array}{l}\text { Cash financing poss. reg. int. and } \\
\text { mach. }\end{array}$ & 0.21 & 0.66 & 0.91 & 1.77 & 0.24 & 0.38 & 1.62 & 14.23 \\
\hline Employment y/y growth rate & 0.30 & 0.07 & 0.04 & 0.07 & 0.28 & 0.02 & 0.00 & 0.01 \\
\hline $\begin{array}{l}\text { Salaries and benefits per emp. } y / y \\
\text { growth rate }\end{array}$ & 0.15 & -0.07 & -0.04 & -0.07 & 0.10 & 0.13 & -0.01 & 0.12 \\
\hline $\begin{array}{l}\text { Intangibles y/y growth in relation } \\
\text { to total assets }\end{array}$ & 0.07 & 0.08 & -0.01 & 0.00 & 0.05 & 0.02 & -0.03 & -0.01 \\
\hline $\begin{array}{l}\text { Investment in intangibles } \\
\text { intensity ratio }\end{array}$ & 0.14 & 0.02 & 0.02 & 0.02 & 0.11 & 0.04 & 0.04 & 0.00 \\
\hline $\begin{array}{l}\text { Machinery } y / y \text { growth in relation } \\
\text { to total assets }\end{array}$ & 0.00 & 0.00 & 0.02 & 0.00 & 0.00 & 0.00 & 0.00 & 0.00 \\
\hline $\begin{array}{l}\text { Investment in machinery intensity } \\
\text { ratio }\end{array}$ & 0.02 & 0.02 & 0.10 & 0.02 & 0.00 & 0.00 & 0.00 & 0.01 \\
\hline $\begin{array}{l}\text { Financial surplus to general } \\
\text { expenses ratio }\end{array}$ & 0.40 & 0.34 & 0.76 & 0.43 & 0.61 & 1.00 & 1.55 & 0.91 \\
\hline $\begin{array}{l}\text { Cash } y / y \text { growth in relation to } \\
\text { total assets }\end{array}$ & -0.21 & 0.00 & 0.00 & -0.02 & -0.07 & 0.09 & -0.05 & 0.13 \\
\hline $\begin{array}{l}\text { Nwc y/y growth in relation to } \\
\text { total assets }\end{array}$ & -0.29 & 0.00 & 0.00 & 0.00 & 0.01 & 0.05 & -0.18 & 0.02 \\
\hline
\end{tabular}

y/y - year to year, st. - short term, cf - cash flows, emp. - employee, nwc - net working capital.

Source: own calculations based on companies' annual reports for 2017. 


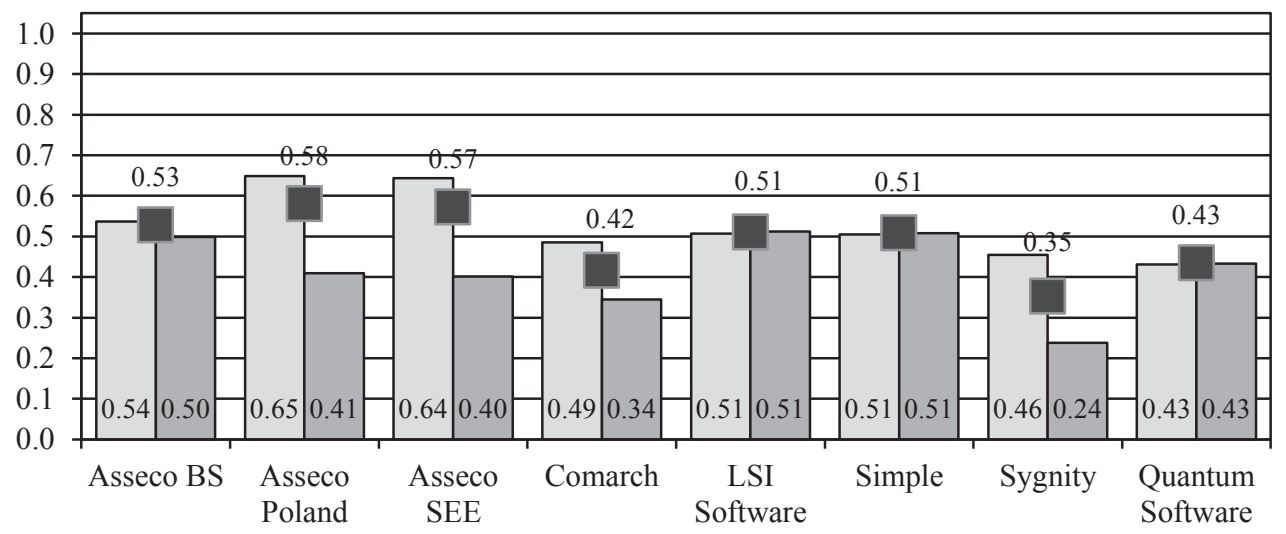

$\square$ Assessment of resources innovative potential

$\square$ Assessment of engagement in resource innovative potential development

aeneral assessment of corporate potential innovativeness

Fig. 5. Final assessments for investigated companies from the corporate potential innovativeness fuzzy model

Source: own calculations.

Table 3. The non-fuzzy output values for investigated companies from intermediate modules of the model

\begin{tabular}{|c|c|c|c|c|c|c|c|c|}
\hline Name of intermediate module of the model & 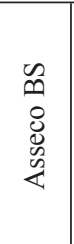 & $\begin{array}{l}\vec{Z} \\
\text { ज्ञ } \\
0 \\
0 \\
0 \\
8 \\
\mathbb{W} \\
\dot{z}\end{array}$ & 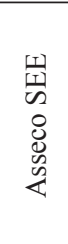 & 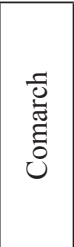 & 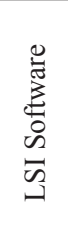 & $\begin{array}{l}\stackrel{0}{\vec{a}} \\
\text { 竞 }\end{array}$ & 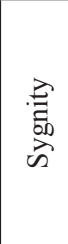 & 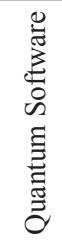 \\
\hline Human capital & 0.77 & 0.97 & 0.87 & 0.67 & 0.58 & 0.54 & 0.81 & 0.53 \\
\hline Knowledge in the form & 0.46 & 0.79 & 0.29 & 0.23 & 0.60 & 0.62 & 0.30 & 0.02 \\
\hline Intellectual resources & 0.61 & 0.85 & 0.58 & 0.45 & 0.59 & 0.58 & 0.55 & 0.28 \\
\hline Material resources & 0.31 & 0.32 & 0.76 & 0.31 & 0.05 & 0.05 & 0.09 & 0.21 \\
\hline Financial liquidity & 0.82 & 0.44 & 0.91 & 0.78 & 0.74 & 0.51 & 0.22 & 0.96 \\
\hline Debt level and servicing & 0.92 & 0.90 & 0.98 & 0.88 & 0.96 & 0.82 & 0.00 & 0.99 \\
\hline Credit rating & 0.84 & 0.65 & 0.92 & 0.80 & 0.82 & 0.66 & 0.14 & 0.96 \\
\hline Financial resources & 0.52 & 0.65 & 0.89 & 0.87 & 0.53 & 0.52 & 0.39 & 0.97 \\
\hline Human capital development & 0.99 & 0.35 & 0.40 & 0.36 & 0.87 & 0.70 & 0.34 & 0.65 \\
\hline Dev. in the area of knowledge in the form of int. assets & 0.83 & 0.55 & 0.21 & 0.26 & 0.73 & 0.39 & 0.17 & 0.19 \\
\hline Engagement in intellectual resources development & 0.88 & 0.44 & 0.32 & 0.32 & $\mathbf{0 . 7 8}$ & 0.52 & 0.28 & 0.37 \\
\hline Engagement in material resources development & 0.32 & 0.30 & 0.91 & 0.35 & 0.24 & 0.23 & 0.21 & 0.24 \\
\hline Cash creation results & 0.25 & 0.44 & 0.47 & 0.37 & 0.25 & 0.83 & 0.25 & 0.85 \\
\hline Engagement in financial resources development & 0.16 & 0.38 & 0.40 & 0.36 & 0.35 & 0.72 & 0.16 & 0.65 \\
\hline
\end{tabular}

Source: own calculations. 
in the outsourcing model), and Asseco Poland by the intellectual resources area (especially human capital).

As for the remaining enterprises, the second highest results were obtained for Asseco BS, LSI Software and Simple, 0.53, 0.51 and 0.51 respectively, which had also the average level of both the main component assessments, and was distinguished slightly in plus in terms of intellectual resources and commitment to their development. Further places were taken by Quantum Software and Comarch with assessments clearly below the average ( 0.43 and 0.42 respectively), which was mainly the result of lower intellectual resources assessments. In turn, the lowest result among the analyzed entities was received for Sygnity (0.35), which in many areas gave way to its competitors.

\section{Conclusions}

The fuzzy model of corporate potential innovativeness assessment, whose practical application has been shown in this paper using the example of eight software developers, can be an interesting alternative or a complement to the so far commonly used methods that are mostly based on survey research. One of its biggest advantages is the possibility of obtaining one final corporate potential innovativeness assessment, as well as others less aggregated, with the use of data from public sources, which additionally are periodic. This enables the fairly current and good orientation in both the general and more in-depth innovativeness potential level of the assessed enterprises, which can be the basis for various comparison analysis and managerial decisions regarding e.g. innovation management, as well as managing corporate image and reputation.

At the same time, however, it must be emphasized that the presented model has still some limitations regarding mainly input data accessibility and comparability between the assessed companies, and requires further considerations regarding especially the verification of the adopted criteria and the definition of a less subjective method of input variables value division between individual fuzzy sets. As in the proposed solution, the emphasis was placed more on quality rather than quantity of resources (their size), further reflection may also be given to the issue of taking into account in the assessment the size of entities, which also directly affects the size of individual resources.

Although the presented solution requires further refinement taking into account the ongoing changes in the increasing information openness of enterprises, in particular in the field of non-financial information [Kamela-Sowińska 2014; Vukić, Vuković, Calace 2017], it should be noted that there are great opportunities ahead of it both in the development dimension as well as the practical application for scientific and managerial purposes. 


\section{Bibliography}

Drucker P., 1992, Innowacja i przedsiębiorczość, PWE, Warszawa.

Francik A., 2003, Sterowanie procesami innowacyjnymi w organizacji, Wydawnictwo Akademii Ekonomicznej w Krakowie, Kraków.

Goldsmith R.E., Foxall G.R., 2003, The Measurement of Innovativeness, [in:] Shavinina L.V. (ed.), The International Handbook on Innovation, Elsevier Science Ltd., Amsterdam.

Hult G., Tomas M., Hurley R.F., Knight G.A., 2004, Innovativeness: its antecedents and impact on business performance, Industrial Marketing Management, vol. 33, no. 5, pp. 429-438.

Hurley R.F., Hult G.T., 1998, Innovation, market orientation and organizational learning, Journal of Marketing, vol. 62, no. 3, pp. 42-54.

Jin Z., Hewitt-Dundas N., Thompson N.J., 2004, Innovativeness and performance: Evidence from manufacturing sectors, Journal of Strategic Marketing, vol. 12, no. 4, pp. 255-266.

Kamela-Sowińska A., 2014, Dyrektywa Unii Europejskiej o ujawnianiu informacji niefinansowych nowe wyzwanie dla rachunkowości, Studia Oeconomica Posnaniensia, vol. 2, no. 4(265), pp. 61-72.

Kotler Ph., 1994, Marketing. Analiza, planowanie, wdrażanie i kontrola, Gebethner i Ska, Warszawa.

Kuratko D.F., Hornsby J.S., Covin J.G., 2014, Diagnosing a firm's internal environment for corporate entrepreneurship, Business Horizons, vol. 57, issue 1, pp. 37-47.

Lev B., 2001, Intangibles: Management, Measurement and Reporting, Brookings Institution Press, Washington D.C.

Mamdani E.H., Assilian S., 1975, An experiment in linguistic synthesis with a fuzzy logic controller, International Journal of Man-Machine Studies, vol. 7, issue 1, pp. 1-13.

Mazzucato M., 2006, Innovation and Stock Prices: A Review of Some Recent Work, Revue de l'OFCE, vol. 97bis, issue 5, pp. 159-179.

Morgan R., Berthon P., 2008, Market orientation, generative learning, innovation strategy and business performance inter-relationships in bioscience firms, Journal of Management Studies, vol. 45, issue 8, pp. 1329-1353.

Nawrocki T.L., 2012, Innowacyjność produktowa przedsiębiorstw. Metodyka oceny na przykładzie spółek giełdowych, CeDeWu, Warszawa.

Nawrocki T.L., 2017, Assessing corporate potential innovativeness, Proceedings of the 7th International Conference on Management - ICoM 2017, pp. 855-863

OECD and Eurostat, 2005, Oslo Manual: Guidelines for Collecting and Interpreting Technological Innovation Data, OECD Publishing, Paris.

OECD, 2015, Guidelines for Collecting and Reporting Data on Research and Experimental Development, The Measurement of Scientific, Technological and Innovation Activities, OECD Publishing, Paris.

Patterson M.L., 1998, From experience: Linking product innovation to business growth, Journal of Product Innovation Management, vol. 15, issue 5, pp. 390-402.

Pawłowski J., 2005, Diagnoza potencjału innowacyjności i konkurencyjności przedsiębiorstw, Przegląd Organizacji, no. 5, pp. 28-30.

Piegat A., 2003, Modelowanie i sterowanie rozmyte, EXIT, Warszawa.

Pomykalski A., 2001, Innowacje, Wydawnictwo Politechniki Łódzkiej, Łódź.

Porter M.E., 1998, Competitive Advantage: Creating and Sustaining Superior Performance, Free Press, New York.

Prahalad C.K., Hamel G., 1990, The Core Competence of the Corporation, Harvard Business Review, vol. 68 , no. 3 , pp. $79-90$.

Rogers E.M., 1995, Diffusion of innovations, Free Press, New York.

Schumpeter J.A., 1960, Teoria rozwoju gospodarczego, PWN, Warszawa. 
Simpson P.M., Siguaw J.A., Enz C.A., 2006, Innovation orientation outcomes: The good and the bad, Journal of Business Research, vol. 59, no. 10-11, pp.1133-1141.

Vukić N.M., Vuković R., Calace D., 2017, Non-financial reporting as a new trend in sustainability accounting, Journal of Accounting and Management, vol. 7, no. 2, pp. 13-26.

Yeung A.C.L., Lai K., Yee R.W.Y., 2007, Organizational learning, innovativeness and organizational performance: A qualitative investigation, International Journal of Production Research, vol. 45, issue 11, pp. 2459-2477.

Zadeh L.A., 1965, Fuzzy sets, Information and Control, vol. 8, issue 3, pp. 338-353.

\section{WYKORZYSTANIE LOGIKI ROZMYTEJ DO OCENY POTENCJALU INNOWACYJNEGO PRZEDSIĘBIORSTW}

Streszczenie: Celem artykułu było przedstawienie empirycznego zastosowania autorskiego modelu oceny i porównania potencjału innowacyjnego przedsiębiorstw. Proponowany model zapewnia podstawę do oceny potencjału innowacyjnego w ujęciu statycznym i dynamicznym z wykorzystaniem logiki rozmytej. Logika rozmyta w przedstawionym rozwiązaniu służy do oceny potencjału innowacyjnego przedsiębiorstw z dwóch perspektyw: zasobów warunkujących działania innowacyjne w przedsiębiorstwie oraz zaangażowania przedsiębiorstwa w ich ciągły rozwój. W tym kontekście zbadano wybrane spółki notowane na Giełdzie Papierów Wartościowych w Warszawie, zaliczane do różnych sektorów gospodarki. Potrzeba pomiaru i oceny innowacyjności przedsiębiorstw w celach zarządczych wynika z coraz większego jej znaczenia w budowaniu wartości przedsiębiorstwa i osiągania długoterminowej przewagi konkurencyjnej.

Słowa kluczowe: potencjał innowacyjny przedsiębiorstwa, ocena innowacyjności, logika rozmyta, model rozmyty Mamdaniego. 